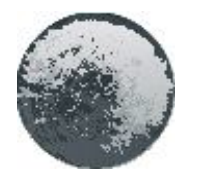

\title{
CHEMISTRY IN THE NEW GENERATION OF UNIVERSITY EDUCATION STANDARDS IN BELARUS
}

\author{
Elena Vasilevskaya, Viktor Khvalyuk \\ Belarusian State University, Minsk, Republic of Belarus
}

\begin{abstract}
The article presents the structure and content of a new generation of post-secondary education standards in Belarus. New educational standards consist of four units: a social science core, a natural science core, a core of professional disciplines, and a selection of special courses. We discuss the place and role of chemistry in new curriculums for students of natural sciences, engineering and humanities.

For chemistry students, the natural science core includes such disciplines as Higher Mathematics, Physics, Ecology, Introduction to Information Technology, Information Technology in Chemistry, and Mathematical Modeling of Chemical Processes and others. In the core of professional disciplines there are classical selection of chemistry courses including Inorganic Chemistry, Analytical Chemistry, Organic Chemistry, Physical Chemistry, Chemistry of Polymers and Biopolymers, Chemical Technology, Instrumental Methods of Chemical Analysis, Physical Methods of Structure Determination, Quantum Chemistry, Crystal chemistry, Structure of Matter, Fundamental Problems of Chemistry, etc.
\end{abstract}

Key words: chemical university education, education standard techniques.

\section{Introduction}

In today's world, rapid development of science and technology calls for innovative models of higher education that can quickly adapt to the demands of the market. In this situation, science education in general and chemistry education in particular form a very important part of post-secondary education.

Three models of organization of post-secondary chemical education can be found today in the world (Chaleckij, 2008). In the first model, the content of chemistry education is regulated by a single national standard (Russia, Ukraine, Poland, Belarus, Kazakhstan). In the second model, a uniform curriculum for a given specialization is used at all universities across the country (e.g., Germany). In the third model, the curriculum is developed within each university (e.g., Bulgaria, Lithuania and Latvia). In any case, the role of national standards is to set and enforce all general and subject-specific requirements for all students regardless of the type and location of their educational institution. International standardization of university education can be effective only if it meets two requirements: (i) national standards are uniform across as many different countries as possible; (ii) these standards remain in force until a predetermined expiry date agreed upon by all participating countries. Only if these conditions are met can educational standards fulfill their role in increasing the quality of education.

According to many authors, one particular feature shared by all educational standards is the idea of "minimal sufficiency". To meet a certain standard means to acquire minimal knowledge and a fixed range of skills that can ensure the quality of education. The requirement of "minimal sufficiency" standards in education sets them apart from other areas such as manufacturing where standardization revolves around the idea of "maximization" (Bratennikova, 1999).

The task of our research is to analyze the place and role of chemical knowledge in the new generation of post-secondary education standards for various specializations in sciences, engineering, and humanities.

The methods employed are the analysis of methodical literature, analysis of documents and contents of standards of post-secondary education in Belarus (2006-2007) and relating it to chemistry education. 


\section{Results of the Research}

There have been several generations of standards of post-secondary education in Belarus (Makarov, 2009). Until the early 2000s, a typical approach was to require students to learn and memorize a fixed collection of ideas and facts (we will refer to this approach as knowledgecentered). New standards introduced recently involve not only mastering the factual information but also learning practical skills and acquiring a basic level of competence in a particular field (the competence-centered approach). This shift in the paradigm offers several advantages: (i) the learning process is geared toward practical application of knowledge; (ii) the role of self-study is increased; (iii) education is more strongly oriented toward professional goals; (iv) students learn how to adapt to new environment.

New educational standards consist of four units: a social science core, a natural science core, a core of professional disciplines, and a selection of special courses (see Table 1). A typical curriculum of this new generation consists of several components required at the national and university levels and an elective component which is at the student's discretion.

Table 1. Structure of a typical curriculum

\begin{tabular}{|c|l|c|c|c|c|}
\hline & & \multirow{2}{*}{ Units } & Weight in the & \multicolumn{3}{|c|}{ Breakdown within each component core } \\
\cline { 4 - 6 } No. & & $\begin{array}{c}\text { required course } \\
\text { load, \% }\end{array}$ & $\begin{array}{c}\text { required at the } \\
\text { the national } \\
\text { level, \% }\end{array}$ & $\begin{array}{c}\text { requiversity } \\
\text { unive } \\
\text { level, \% }\end{array}$ & Elective, \% \\
\hline I & Social science core & $14-16$ & $85-90$ & $10-15$ & - \\
\hline II & Natural science core & $6-30$ & $60-70$ & $25-30$ & $10-15$ \\
\hline III & $\begin{array}{l}\text { Professional disci- } \\
\text { plines }\end{array}$ & $45-65$ & $60-70$ & $20-25$ & $10-15$ \\
\hline IV & Special courses & $10-15$ & - & - & - \\
\hline
\end{tabular}

The content of the social science core is the same for all university departments and is set by a separate standard of the Republic of Belarus (2006). The required component of this core of subjects includes such disciplines as "History of Belarus", "Philosophy", "Psychology", "Education", "Foreign language" and some others. The elective component consists of at least three disciplines totaling 152 hours including 52 contact hours.

The natural science core is mandatory for students of all specialities including humanities. This ensures that all graduates have a certain level of science literacy in a world where science and technology play an increasingly important role. An important consideration here is what level of competence in natural sciences a university graduate should possess. It is obvious that the simplest possible answer-to know the material-is not the right one. First, it is impossible to master even the basics of all natural sciences within the time available (the natural science component can be as low as $6 \%$ of all course load for students in humanities). Second, most of the knowledge in natural sciences acquired by a student of humanities is unlikely to be ever needed in practices. Therefore, science education for students of humanities should focus not so much on building a solid background of factual information as on providing an impetus for independent reflection on the place and role of science in general. To this goal, it is essential that students accumulate enough expose to scientific ideas to lead a comfortable existence in today's world and respond to its increasing demands. On the other hand, one would also emphasize practical application of chemical knowledge.

According to the new university standard, an integrated course titled "Fundamentals of modern natural sciences" is taught to all students in humanities (Dynich, 2008). As a result of studying the chemistry component of this course students learn about: 
- $\quad$ main concepts, principles, and laws of modern chemistry;

- chemical processes which are used in modern technology and in everyday life;

- the structure of matter and the laws of conservation of matter and energy;

- relationship between chemical structure and reactivity;

- modern techniques of chemical analysis and structure determination;

- environmental hazards associated with chemical production and industry.

They will also know:

- how to control chemical reactions by varying reaction conditions;

- properties and applications of polymers, metals and alloys, silicate-based materials, biologically active compounds;

- principles of rational consumptions of natural resources and environmental protection.

Finally, students will be able to:

- explain the existence of the great variety of chemical substances;

- understand the atomistic nature of chemical substances and possibilities of chemical introversion;

- use the knowledge of chemistry in their professional activities;

- adapt their personal behavior in response to the awareness of the influence of chemistry on the natural environment.

In the natural science core, there is a general chemistry course intended for future engineers, and some chemical courses for chemistry and biology educators (ES RB 1-02 $0406-$ 2008).

For instance, the structure of the standardized curriculum for the specialization "Chemistry" (Catalog No. 1 -31 05 01-01) is given in Table 2 (ES RB 1-31 05 01-2008).

Table 2. Standardized curriculum for the specialization "Chemistry"

\begin{tabular}{|c|c|c|c|c|c|}
\hline \multirow{3}{*}{ No. } & \multirow{3}{*}{ Units } & \multicolumn{3}{|c|}{ Number of hours } & \multirow{3}{*}{ Credits } \\
\hline & & \multirow{2}{*}{ Total } & \multicolumn{2}{|l|}{ breakdown } & \\
\hline & & & contact hours & self-study & \\
\hline $\mathbf{I}$ & Social science core & $1568^{1)}$ & $\begin{array}{c}744 \\
(15.4 \%)\end{array}$ & 348 & 42 \\
\hline 1.1 & Nationally mandated component & $1416^{1)}$ & 642 & 298 & 36 \\
\hline 1.2 & Elective component & 152 & 52 & 50 & 6 \\
\hline II & Natural science core & 1546 & $\begin{array}{c}\mathbf{1 0 4 2} \\
(21.7 \%) \\
\end{array}$ & 504 & 61 \\
\hline 2.1 & Nationally mandated component & 954 & 654 & 300 & 38 \\
\hline 2.2 & University-mandated component & 400 & 286 & 114 & 17 \\
\hline 2.3 & Elective component & 192 & 102 & 90 & 6 \\
\hline III & Professional disciplines & 3650 & $\begin{array}{c}2298 \\
(47.6 \%)\end{array}$ & 1352 & 130 \\
\hline 3.1 & Nationally mandated component & 2470 & 1564 & 906 & 93 \\
\hline 3.2 & University-mandated component & 772 & 476 & 296 & 28 \\
\hline 3.3 & Elective component & 408 & 258 & 150 & 9 \\
\hline IV & Special courses & 1124 & $\begin{array}{c}\mathbf{7 4 0} \\
(15.3 \%)\end{array}$ & 384 & 39 \\
\hline & Total: & $7^{7888^{1)}}$ & 4824 & 2588 & 272 \\
\hline
\end{tabular}

${ }^{\mathrm{I})}$ Including 476 hours of sports training. 
For chemistry students, the nationally-mandated component of the natural science core includes such disciplines as Higher Mathematics, Physics, Ecology, Introduction to Information Technology and others. The university-mandated component includes History of Chemistry, Information Technology in Chemistry, and Mathematical Modeling of Chemical Processes.

In the core of professional disciplines, the nationally-mandated component consists of a classical selection of chemistry courses including Inorganic Chemistry, Analytical Chemistry, Organic Chemistry, Physical Chemistry, Chemistry of Polymers and Biopolymers, Chemical Technology, etc. The university-mandated component includes Instrumental Methods of Chemical Analysis, Physical Methods of Structure Determination, Quantum Chemistry, Crystal chemistry, Structure of Matter, Fundamental Problems of Chemistry, etc.

Apart from the coursework (lectures, seminars, and labs), the chemistry curriculum involves examinations, optional courses, practical training, research projects, and the state examination.

Each student studying under Chemistry Program No. 1-31 0501 chooses to enroll into one of the following four programs: academic and industrial research, chemical education, pharmaceutical chemistry, and environmental studies. All four programs have the same nationally-mandated components in the social science, natural science and professional discipline cores but differ by their selection of the university-mandated parts of the curriculum, elective components, and special courses. For example, students of pharmaceutical chemistry take several special courses such as Biotechnology, Bioenergetics, Polymer Chemistry in Medicine, Metal Complexes in Medicine, Drug Manufacturing, Pharmaceutical Analysis, Methods of Drug Certification, Analytical Chemistry of Narcotic Substances, Pharmaceutical Homeopathy, Biochemistry of Information-Carrying Macromolecules, etc.

\section{Conclusion}

Realization of a new generation of educational standards gives possibility for modernization of educational process, provide goals for students learning and emphasize new ways of teaching and learning. New standards are intended to delineate what natural science knowledge every student should know and understand. Students of all specialties can see few connections between natural science courses and their future careers.

For chemistry students new educational standards give traditional courses in nationallymandated component and contemporary discipline in university-mandated and elective components. It is also important to resolve some problems in higher chemical education which touch to reflection of the modern state of chemistry investigations in the content of corresponding courses and advancing character of the contents of chemical education in response to practical needs.

\section{References}

Браценнікава А. М. (1999). Стандартызацыя як сродак канструявання школьнага курса хіміі // Народная асвета. №6. С. 66-72; №7. С. 36-42. (in Belarussian).

Халецкий, В. А., Василевская Е.И. (2008). Место и роль химии в стандартах и образовательных программах для студентов инженерных специальностей. Вышэйшая школа, № 3, с. $60-65$.

Дынич, В. И. Толкачев Е. А., Василевская Е. И., Павлова О. С., Белоусова Н. А. (2008). Основы современного естествознания (проект программы курса). Вышэйшая школа, № 3 , с. 42 49.

Макаров А.В., Перфильев Ю.С., Федин В.Т. (2009). Стандарты высшего образования нового поколения: сравнительный анализ. Минск: РИВШ, 268 с. 
ОСРБ 1-02 04 06-2008. Образовательный стандарт Республики Беларусь. Высшее образование. Первая ступень. Специальность «Химия» с дополнительной специальностью 1-02 04 06-01 «Биология».

ОС РБ 1-31 05 01-2008 Образовательный стандарт Республики Беларусь. Высшее образование. Первая ступень. Специальность 1-31 0501 Химия (по направлениям).

РД РБ 02100.5.227-2006. Образовательный стандарт. Высшее образование. Первая ступень. Цикл социально-гуманитарных дисциплин.

Received 22 June 2009; accepted 29 November 2009

\begin{tabular}{|l|l|}
\hline$\square$ & \multicolumn{1}{|c|}{$\begin{array}{l}\text { Elena Vasilevskaya } \\
\text { Viktor Khvalyuk }\end{array}$} \\
$\begin{array}{l}\text { Dr., Associate Professor, Belarusian State Univer- } \\
\text { sity, Department of chemistry, Chair of inorganic } \\
\text { chemistry. }\end{array}$ & $\begin{array}{l}\text { Dr., Associate Professor, Belarusian State Univer- } \\
\text { sity, Department of chemistry, Chair of general } \\
\text { chemistry. }\end{array}$ \\
\begin{tabular}{l} 
E-mail: Vasileli@bsu.by \\
\hline
\end{tabular} & \begin{tabular}{l} 
E-mail: khvalyuk@gmail.com \\
\hline
\end{tabular}
\end{tabular}

